\title{
In vitro screening of Amazonian plants for hemolytic activity and inhibition of platelet aggregation in human blood
}

\author{
Viviana Maria Araújo de OLIVEIRA ${ }^{1}$, Ana Lucia Basilio CARNEIRO², Glaucia Socorro de Barros CAUPER ${ }^{3}$, \\ Adrian Martin POHLIT ${ }^{4}$
}

\begin{abstract}
In the present study, different aerial parts from twelve Amazonian plant species found in the National Institute for Amazon Research's (INPA's) Adolpho Ducke Forest Reserve (in Manaus, Amazonas, Brazil) were collected. Separate portions of dried, ground plant materials were extracted with water (by infusion), methanol and chloroform (by continuous liquidsolid extraction) and solvents were removed first by rotary evaporation, and finally by freeze-drying which yielded a total of seventy-one freeze-dried extracts for evaluation. These extracts were evaluated initially at concentrations of 500 and $100 \mu \mathrm{g} /$ $\mathrm{mL}$ for in vitro hemolytic activity and in vitro inhibition of platelet aggregation in human blood, respectively. Sixteen extracts ( $23 \%$ of all extracts tested, $42 \%$ of all plant species), representing the following plants: Chaunochiton kappleri (Olacaceae), Diclinanona calycina (Annonaceae), Paypayrola grandiflora (Violaceae), Pleurisanthes parviflora (Icacinaceae), Sarcaulus brasiliensis (Sapotaceae), exhibited significant inhibitory activity towards human platelet aggregation. A group of extracts with antiplatelet aggregation activity having no in vitro hemolytic activity has therefore been identified. Three extracts $(4 \%)$, all derived from Elaeoluma nuda (Sapotaceae), exhibited hemolytic activity. None of the plant species in this study has known use in traditional medicine. So, these data serve as a baseline or minimum of antiplatelet and hemolytic activities (and potential usefulness) of non-medicinal plants from the Amazon forest. Finally, in general, these are the first data on hemolytic and inhibitory activity on platelet aggregation for the genera which these plant species represent.
\end{abstract}

KEYWORDS: Adolpho Ducke Reserve, Chaunochiton kappleri, Diclinanona calycina, Elaeoluma nuda.

\section{Testes in vitro de plantas Amazônicas para atividade hemolítica e inibição da agregação plaquetária em sangue humano}

\section{RESUMO}

No presente estudo, partes aéreas obtidas de doze (12) espécies vegetais da Amazônia encontradas na Reserva Florestal Adolpho Ducke (localizada na cidade de Manaus, Estado do Amazonas, Brasil) do Instituto Nacional de Pesquisas da Amazônia foram coletadas, secadas e moídas. Porções dos materiais vegetais em pó foram extraídas com água (por infusão), metanol e clorofórmio (por extração líquido-sólido contínua) e os solventes foram removidos por evaporação rotatória e finalmente liofilização, forneceram um total de setenta e one (71) extratos liofilizados. Esses extratos foram avaliados inicialmente para atividade hemolítica in vitro e atividade inibitória da agregação plaquetária em sangue humano in vitro em concentraçóes de 500 e 100 Hg/ $\mathrm{mL}$, respectivamente. Dezesseis (16) extratos (23\% dos extratos testados, $42 \%$ das espécies vegetais) representando as seguintes plantas, apresentaram inibição significativa frente a agregação de plaquetas humanas in vitro: Chaunochiton kappleri (Olacaceae), Diclinanona calycina (Annonaceae), Paypayrola grandiflora (Violaceae), Pleurisanthes parviflora (Icacinaceae), Sarcaulus brasiliensis (Sapotaceae). Como principal resultado, um grupo de extratos apresentando atividade inibitória da agregaçáo plaquetária e em que não há atividade hemolítica in vitro foi identificado. Três (3) extratos (4\% do total de extratos testados), todos obtidos a partir de Elaeoluma nuda (Sapotaceae), apresentaram atividade hemolítica. Nenhuma das espécies vegetais nesse estudo tem uso medicinal conhecido. Assim, esses dados servem de linha base ou mínimas das atividades antiplaquetária e hemolítica (e utilidade potencial) de plantas da floresta Amazônica. Finalmente, em geral, esses dados são os primeiros disponíveis sobre ação hemolítica e inibição da agregação plaquetária dos gêneros representados por essas espécies de plantas.

PALAVRAS-CHAVE: Reserva Florestal Adolpho Ducke, Chaunochiton kappleri, Diclinanona calycina, Elaeoluma nuda.

\footnotetext{
1 Universidade Federal do Amazonas. E-mail: viviana.araujo@hotmail.com

2 Universidade Federal do Amazonas. E-mail: acarneiro@uea.edu.br

3 Instituto Nacional de Pesquisas da Amazônia. E-mail: glauciacauper@yahoo.com.br

${ }^{4}$ Instituto Nacional de Pesquisas da Amazônia. E-mail: ampohlit@inpa.gov.br
} 


\section{INTRODUCTION}

The Amazon region represents the most extensive tropical forest ecosystem in the world and is considered to be the largest single reserve in terms of medicinal plants. Estimates put the total number of plant species in this region at as many as 125,000 and the number of traditionally-used medicinal plant species at between 5,000 and 10,000 (Gurib-Fakim, 2006). A large number of medicinal plants owe their discovery to Amerindians who detain and associate an ever-richer traditional knowledge to these plant species with the passing of time. Only about 5-10 \% of all Amazonian plants have been the object of at least one study on pharmacological activity or chemical composition (Gurib-Fakim, 2006). Besides traditional knowledge as an important source of medicinal and pharmacological information on the utility, both potential and direct, of plant biodiversity, it is important to recognize a complementary or unique niche for bioprospection based on random sampling techniques (that is, sampling which does not rely on traditional medicine, chemosystematics or specific, prior knowledge of plant properties).

This method can be used to locate, evaluate, and systematically exploit the biodiversity of a given location, especially in the pursuit of genetic, biochemical and pharmaceutical resources for commercial ends. It should also be recognized that traditional knowledge may not always be easy to access for a number of reasons and its interpretation is not always straight forward in light of modern pharmacological and biochemical understanding of disease and normal functioning of healthy organisms.

Among the most important and costly causes of hospitalization today are heart disease and stroke. The evaluation of platelet function is a crucial datum in establishing necessary therapeutic measures associated with each clinical case. Platelets are important players in the processes responsible for the control of bleeding (hemostasis) and the formation of clots in injured blood vessels (thrombosis). For this reason, the pharmacological basis for therapy and prevention of cardiovascular disturbances is platelet structure and specific function (Jensen \& Gordon, 1992).

The use of drugs having the capability to reduce platelet activity, such as acetyl salicylic acid (aspirin), requires periodic check-ups on the impact of these pharmaceuticals on platelet aggregation. Laboratory evaluation of platelet aggregation permits the measurement of qualitative and semi-quantitative temporal parameters of platelet function in the presence of several aggregation-provoking agents such as adenosine diphosphate (ADP), collagen (COL), adrenalin (ADR), thrombin and arachidonic acid (AA). Quantification can be performed on platelet-rich fractions or on whole blood samples. In comparison to other tests which evaluate primary hemostasis, this technique seems to represent the best auxiliary laboratory diagnostic test for the verification of acquired or congenital qualitative disturbances of platelet function (Zucker, 1989).

Many in vitro and in vivo studies have been performed to evaluate the antiaggregant action of natural products as a means to drug lead discovery. These studies are important since some patients present resistance to aspirin (5-45\% of users) (Undas et al., 2007) and/or use conventional medication (warfarin, aspirin) in association with medicinal plant formulations (Panax ginseng C.A. Mey., Allium sativum L., Ginkgo biloba L., Matricaria chamomilla L., Angelica sinensis (Oliv.) Diels, Camellia sinensis L., Salvia miliorrhiza Bunge, Zingiber officinale Roscoe). These are the most studied species because they can inhibit or increase the anticoagulant or antiplatelet aggregation effects (Basila \& Yuan, 2005; Saw et al., 2006).

In recent years, many antiplatelet aggregating agents have been isolated from plants and have demonstrated potent activity (Dong et al., 1998). Important classes of natural antiaggregant compounds are flavonoids such as quercetin and myricetin (Hommam et al., 2000), and flavones chrysin and apigenin (Landolfi et al., 1984). In the investigation of the action of plant extracts on human blood, besides platelet function, it is important to determine any hemolytic activity as this is an indicator of general cytotoxicity and bioactivity. In vitro testing for hemolytic action has been used as one of the methods of triage for different toxic agents (Kublik et al., 1996). The in vitro hemolysis test has also been employed by many different groups for the toxicological evaluation of different plants (Gandhi \& Cherian, 2000).

Considering the richness and potential of the Amazon flora, the present study has as its primary goal the prospection of extracts prepared from the following twelve plant species for hemolytic activity and inhibition of platelet aggregation in human blood: Moutabea guianensis Aubl. (Polygalaceae), Thyrsodium spruceanum Benth. (Anacardiaceae), Sarcaulus brasiliensis (A.DC.) Eyma (Sapotaceae), Chaunochiton kappleri (Sagot ex Engl.) Ducke (Olacaceae), Paypayrola grandiflora Tul. (Violaceae), Schoenobiblus daphnoides Mart. (Thymelaeaceae), Elaeoluma nuda (Baehni) Aubrév. (Sapotaceae), Pleurisanthes parviflora (Ducke) Howard (Icacinaceae), Diclinanona calycina Benoiste (Annonaceae), Lacmellea gracilis (Mull. Arg.) Markgr. (Apocynaceae), Dilkea johannesii Barb. Rodr. (Passifloraceae) and Sterigmapetalum obovatum Kuhlm. (Rhizophoraceae).

What these plant species have in common is that they are found in the western Brazilian Amazon (in the National Institute for Amazon Research's Adolpho Ducke Forest Reserve) (Ducke Reserve, 2004) in Manaus, Amazonas, Brazil. In an earlier study, antibacterial and antifungal properties of these twelve species were investigated and several of these species proved to have significant inhibitory activity towards 
strains of bacteria and fungi associated with human diseases (Carneiro et al., 2008). The present study therefore represents a further expansion on the available knowledge of the in vitro biological activity of these non-medicinal species from the western Amazon forest.

\section{MATERIAL AND METHODS}

\section{PLANT MATERIALS}

The plants studied are from non-flooding, or terra firme, regions and were catalogued during INPA's Flora Project at the Adolpho Ducke Forest Reserve (Ducke Reserve, 2004; Table 1). Starting from a complete list of families and genera of plants found in the Ducke Reserve, systematic literature searching was performed to identify a group of genera having few or no previous chemical composition or pharmacological studies. From this larger group of genera, a sub-group of twelve species having no relevant prior study, availability in

the Reserve, and a previously identified Flora Project fertile voucher on deposit at the INPA Herbarium were chosen to represent 12 plant families found in this forest area. Collection was performed from February to June, 2004. Plant specimens (Table 1) were located based on polar coordinates and field tags on individual specimens as provided by the Flora Project. Freshly collected leaves and branches were weighed and then dried at less than $50^{\circ} \mathrm{C}$ in an oven under incandescent lamps. Dried samples were weighed and then each plant part was separately ground. Pulverized plant materials were stored in impermeable plastic bags under incandescent lighting at room temperature (ca. $\left.27^{\circ} \mathrm{C}\right)$.

\section{CALCULATION OF PERCENT WEIGHT LOSS UPON DRYING}

From the difference in weight of each plant material at the time of collection (fresh, FW) and the weight after drying (DW), the weight-loss upon drying was calculated as a percentage (WLD\%) using the following formula: WLD\% $=100 \times[1-(\mathrm{DW} / \mathrm{FW})]$

\section{PREPARATION OF EXTRACTS}

Each dried, ground plant material was divided into three portions which were separately extracted with methanol, chloroform (continuous liquid-solid extraction) and water (infusion). Rotary evaporation under reduced pressure was used to remove solvents followed by freeze-drying. This procedure resulted in seventy-one freeze-dried extracts which were sealed in glass vessels and stored at $-20^{\circ} \mathrm{C}$.

\section{HUMAN BLOOD SAMPLES}

IVenous blood samples $(5 \mathrm{~mL})$ were collected using plastic or silicone-coated materials from volunteer donors after obtaining prior consent. Donors were screened to guarantee that none had ingested drugs such as aspirin or other anti- inflammatory agents for a period of at least 10 days prior to donation, since these compounds could be a source of nonsystematic alteration in platelet function.

Anticoagulant human blood was centrifuged (1000 rpm for $5 \mathrm{~min}$ at room temperature). The supernatant was collected as platelet-rich plasma (PRP). After PRP was removed, residual plasma was centrifuged at $3000 \mathrm{rpm}$ for $15 \mathrm{~min}$ and the supernatant was collected as platelet-poor plasma (PPP). PRP was stabilized with $3.8 \%$ sodium citrate (anticoagulant) at a proportion of 1:9. The platelet number was determined (manual chamber method - hemolyzing $1 \%$ ammonium oxalate solution) and adjusted to $3 \times 105 / \mathrm{mm}^{3}$ by mixing PRP and PPP with the aid of a platelet counter.

\section{IN VITRO HEMOLYTIC ACTIVITY}

For this experiment, $1 \%$ red-blood cell suspension in $\mathrm{pH} 7.4$ phosphate buffer was used throughout in the preparation of experimental (test) and control tubes (WHO, 1998). Extracts prepared as described above were initially dissolved in dimethylsulphoxide (DMSO), ethyl alcohol or distilled water at known sample concentrations. These sample solutions were transferred by micropipette to test tubes containing a fixed volume of red-blood cell suspension. The extracts were screened at test concentrations of 500, 250,100 and $50 \mu \mathrm{g} / \mathrm{mL}$. Hemolytic activity of extracts was evaluated by comparison with the effects of the commercially available positive control saponin from quillaja bark (Sigma, U.S.A.). This control provides total hemolysis of red-blood cell suspensions at concentrations of $10-20 \mu \mathrm{g} / \mathrm{mL}$. Negative controls (blanks) contained $1 \%$ solvent (DMSO, ethanol or distilled water) in red-blood cell suspension.

The result for each test concentration of extract was interpreted qualitatively in vitro hemolytic action either being present or absent. Overall, the result was a semi-quantitative evaluation of hemolytic activity for each extract in accordance with international guidelines for the evaluation of this activity in medicinal plant materials (WHO, 1998).

\section{IN VITRO PLATELET AGGREGATION MEASUREMENT}

In the platelet aggregation assay, $\mathrm{PRP}$ activity/aggregation was determined spectrophotometrically using a multi-channel automated aggregometer (Chronolog Corporation, Model 400, U.S.A.) according to the method described by Born (1962). This apparatus can furnish data on the platelet activity of several samples simultaneously. $10 \mu \mathrm{L}$ of agonists $\operatorname{ADP}(10 \mu \mathrm{M})$, ADR $(10 \mathrm{mg} / \mathrm{L})$ and $\mathrm{COL}(5 \mathrm{mg} / \mathrm{L})$, which induce platelet aggregation, were added to PRP $(400 \mu \mathrm{L})$ and the variation of light transmittance was registered over time. Increase in transmittance is associated with the degree of platelet aggregation (Born, 1962). Acetylsalicylic acid $(30 \mathrm{mg} / \mathrm{L})$ (Pharma Nostra, Anápolis, Brasil) was used as positive control for platelet aggregation (Sanabria et al., 1997) 
and $0.5 \%$ DMSO was used as negative control. Extracts were initially screened at a concentration of $100 \mu \mathrm{g} / \mathrm{mL}$ for inhibition-inducing activity towards the above-mentioned agonists. Those extracts presenting inhibitory activity of platelet aggregation $>97 \%$ (relative to the inhibition induced by the aspirin controls) were next tested at different dilutions to establish minimum inhibitory concentrations (MIC). Percent inhibition (I\%) of platelet aggregation was calculated according to the equation: $\mathrm{I} \%=100 \times[1-(\mathrm{SA} \% / \mathrm{CA} \%)]$, where $S A \%$ is the measured percentage aggregation observed for the sample (extract) and CA\% is the measured percentage aggregation observed for the control.

\section{TESTS FOR PHENOLS, TANNINS AND SAPONINS}

Each extract $(10 \mathrm{mg})$ was dissolved in solvent $(5 \mathrm{~mL})$ in a test tube and $10 \%$ iron (III) chloride solution $(100 \mu \mathrm{L})$ was added. Color change or precipitate formation is indicative of a positive result as compared to blank (solvent + iron (III) chloride solution). Blue, blue-green and red initial coloration is indicative of the presence of phenolic compounds after complex formation. Dark, blue- or green-colored precipitate indicated the presence of tannins. Saponin containing extracts presented long-lasting foam heads after shaking of the extract dissolved in water.

\section{TEST FOR FLAVONOIDS}

Methanol solution of each extract $(3 \mathrm{~mL})$ was placed in a test tube together with three pieces of magnesium metal. Concentrated hydrochloric acid $(1 \mathrm{~mL})$ was added slowly. After effervescence had seized, a rose or red-colored solution was considered a positive result. This reaction is known as the cyanidin, Shinoda or hydrogenation (III) reaction (Matos, 1997).

\section{RESULTS AND DISCUSSION}

Twelve Amazonian plant species representing twelve families were screened in the present work. Herbarium voucher numbers, parts of each plant species studied and drying and extraction data are presented in Table 1.

Of a total of seventy-one extracts tested only three extracts ( $4 \%$ of the total tested) from $E$. nuda (8\% of all species tested) presented significant hemolytic activity. Thus, $E$. nuda leaf methanol extracts presented hemolytic action at a concentration of $500 \mu \mathrm{g} / \mathrm{mL}$ while branch methanol and water extracts presented hemolytic action at concentrations of $250 \mu \mathrm{g} / \mathrm{mL}$.

A large number of compounds from different sources have been found to be responsible for in vitro hemolysis. Among these are substances derived from plants (Gandhi and Cherian, 2000), heavy metals (Ribarov \& Bemov, 1981) and pharmaceuticals (Yamamoto et al., 2001). The direct hemolytic effect of different toxic agents is due to a variety of non-specific mechanisms. For example, surfactants cause hemolysis through dissolution of the erythrocyte plasma membrane which ruptures due to increased fragility or due to osmotic lysis caused by increased permeability of the plasma membrane (Aparicio et al., 2005). On the other hand, reduced xenobiotic compounds, such as phenols, are capable of promoting hemolysis through oxidation of hemoglobin, forming metahemoglobin (Bukowska \& Kowalska, 2004). Bilirubin promotes the loss of lipids in the erythrocyte plasma

Table 1 - Species and family names, herbarium voucher numbers, drying and extraction data for the twelve plants screened in this study.

\begin{tabular}{|c|c|c|c|c|c|c|c|c|c|c|}
\hline \multirow{3}{*}{ Species } & \multirow{3}{*}{ Family } & \multirow{3}{*}{ Voucher No. } & & & \multicolumn{6}{|c|}{ Extract Yield (w/w, \%) } \\
\hline & & & \multicolumn{2}{|c|}{ Weight loss on drying (\%) } & \multicolumn{3}{|c|}{ Leaves } & \multicolumn{3}{|c|}{ Branches / Vines } \\
\hline & & & Leaves & Branches/Vines & $\mathrm{CH}_{3} \mathrm{OH}$ & $\mathrm{CHCl}_{3}$ & $\mathrm{H}_{2} \mathrm{O}$ & $\mathrm{CH}_{3} \mathrm{OH}$ & $\mathrm{CHCl}_{3}$ & $\mathrm{H}_{2} \mathrm{O}$ \\
\hline Chaunochiton kappleri & Olacaceae & 181856 & 66,6 & 22.8 & 19.4 & 4.1 & 18.6 & 7.8 & 1.3 & 5.9 \\
\hline Diclinanona calycina & Annonaceae & 179085 & 55.3 & 46.0 & 36.8 & 12.2 & 16.3 & 5.2 & 1.8 & 6.0 \\
\hline Dilkea johannesii & Passifloraceae & 206552 & 62.4 & 50.5 & 10.3 & 2.6 & 7.9 & 4.4 & 0.7 & 2.4 \\
\hline Elaeoluma nuda & Sapotaceae & 179316 & 47.0 & 56.5 & 32.2 & 7.8 & 15.9 & 12.3 & 3.0 & 7.2 \\
\hline Lacmellea gracilis & Apocynaceae & 189617 & 70.9 & 44.9 & 30.3 & 8.8 & * & 5.3 & 1.2 & 4.2 \\
\hline Moutabea guianensis & Polygalaceae & 179914 & 58.2 & 46.3 & 8.3 & 3.0 & 10.8 & 4.9 & 1.3 & 8.4 \\
\hline Paypayrola grandiflora & Violaceae & 185700 & 42.9 & 45.9 & 17.6 & 3.8 & 7.7 & 3.7 & 1.2 & 3.5 \\
\hline Pleurisanthes parviflora & Icacinaceae & 195327 & 55.2 & 42.2 & 14.7 & 4.6 & 13.2 & 4.8 & 1.5 & 7.2 \\
\hline Sarcaulus brasiliensis & Sapotaceae & 183442 & 44.5 & 40.7 & 17.0 & 3.4 & 7.7 & 7.1 & 2.7 & 8.2 \\
\hline Schoenobiblus daphnoides & Thymelaeaceae & 191794 & 21.8 & 25.3 & 18.7 & 4.1 & 19.0 & 13.9 & 2.3 & 5.4 \\
\hline Sterigmapetalum obovatum & Rhizophoraceae & 183424 & 52.1 & 56.0 & 17.1 & 5.7 & 14.2 & 7.8 & 1.4 & 6.9 \\
\hline Thyrsodium spruceanum & Anacardiaceae & 178282 & 55.0 & 49.0 & 19.2 & 4.1 & 10.5 & 10.2 & 2.7 & 3.5 \\
\hline
\end{tabular}

Notes. * - formed solid emulsion, yield data could not be calculated. This extract was not tested. 
membrane, with exposure of residues of phosphatidyl serine (Brito et al., 2002). Saponins, used in the present study as positive control for evaluation of hemolytic action, produce changes in the erythrocyte membrane, causing rupture and release of characteristic hemoglobin pigments.

A total of seventy-one extracts were tested for inhibition of platelet aggregation caused by three different agonists. Sixteen extracts ( $23 \%$ of all extracts tested) proved to be active inhibitors of platelet aggregation ( $\geq 75 \%$ inhibition) at a concentration of $100 \mathrm{mg} / \mathrm{L}$ (Table 2). All experimental values were referenced to the inhibitory activity of the aspirin standard. Extracts (five in all) presenting $\geq 97 \%$ inhibitory activity were considered highly active and were diluted and further screened to establish minimum inhibitory concentrations (MIC, Table 3). Branch chloroform extracts of C. kappleri presented very good inhibitory potential towards platelet aggregation promoted by agonists ADR and COL (MIC 25.0 and $16.6 \mu \mathrm{g} / \mathrm{mL}$, respectively). Leaf chloroform extract of $P$. grandiflora presented MIC of $25 \mu \mathrm{g} /$ $\mathrm{mL}$ against the effects of ADR. Leaf methanol extract of $P$. parviflora (MIC $16.6 \mu \mathrm{g} / \mathrm{mL}$ ) and branch methanol extract of D. calycina (MIC $25 \mu \mathrm{g} / \mathrm{mL}$ ) inhibited platelet-aggregation promoted by COL. In general, the studied extracts presented

Table 2 - Average inhibition of platelet aggregation [as percentage of effect of positive control (acetylsalicylic acid) in three different agonist systems] for studied Amazonian plant extracts at concentrations of $100 \mathrm{mg} / \mathrm{L}$.

\begin{tabular}{|c|c|c|c|c|c|}
\hline \multirow[t]{2}{*}{ Species } & \multirow[t]{2}{*}{ Part } & \multirow{2}{*}{$\begin{array}{c}\text { Extraction } \\
\text { Solvent }\end{array}$} & \multicolumn{3}{|c|}{$\begin{array}{c}\text { Platelet Aggregating Agent } \\
\text { (Avg \% inhibition) }\end{array}$} \\
\hline & & & ADP & ADR & $\mathrm{COL}$ \\
\hline \multirow{6}{*}{ Chaunochiton kappleri } & \multirow{3}{*}{ Leaf } & $\mathrm{CHCl}_{3}$ & 9 & 3 & 6 \\
\hline & & $\mathrm{CH}_{3} \mathrm{OH}$ & 61 & 49 & 66 \\
\hline & & $\mathrm{H}_{2} \mathrm{O}$ & 61 & 86 & 84 \\
\hline & \multirow{3}{*}{ Branch } & $\mathrm{CHCl}_{3}$ & 75 & 98 & 99 \\
\hline & & $\mathrm{CH}_{3} \mathrm{OH}$ & 12 & 20 & 39 \\
\hline & & $\mathrm{H}_{2} \mathrm{O}$ & 59 & 78 & 72 \\
\hline \multirow{6}{*}{ Diclinanona calycina } & \multirow{3}{*}{ Leaf } & $\mathrm{CHCl}_{3}$ & 11 & 5 & 21 \\
\hline & & $\mathrm{CH}_{3} \mathrm{OH}$ & 56 & 30 & 89 \\
\hline & & $\mathrm{H}_{2} \mathrm{O}$ & 18 & 33 & 36 \\
\hline & \multirow{3}{*}{ Branch } & $\mathrm{CHCl}_{3}$ & 9 & 35 & 95 \\
\hline & & $\mathrm{CH}_{3} \mathrm{OH}$ & 33 & 88 & 97 \\
\hline & & $\mathrm{H}_{2} \mathrm{O}$ & 22 & 19 & 31 \\
\hline \multirow{6}{*}{ Dilkea johannesii } & \multirow{3}{*}{ Leaf } & $\mathrm{CHCl}_{3}$ & 11 & 9 & 31 \\
\hline & & $\mathrm{CH}_{3} \mathrm{OH}$ & 0 & 0 & 18 \\
\hline & & $\mathrm{H}_{2} \mathrm{O}$ & 2 & 0 & 7 \\
\hline & \multirow{3}{*}{ Branch } & $\mathrm{CHCl}_{3}$ & 4 & 0 & 0 \\
\hline & & $\mathrm{CH}_{3} \mathrm{OH}$ & 17 & 6 & 0 \\
\hline & & $\mathrm{H}_{2} \mathrm{O}$ & 15 & 4 & 0 \\
\hline
\end{tabular}

a greater tendency towards inhibition of platelet-aggregation promoted by COL.

Antiaggregant activity has previously been demonstrated for some known medicinal plants. For example, Bydlowski $e t$ al. (1988) demonstrated platelet antiaggregant properties in vivo and in vitro for the whole fruit of the Amazonian tree-vine guaraná (Paullinia cupana). In an in vitro and ex vivo study, Son et al. (2004) observed that green tea (Camellia sinensis) catechins inhibit in vitro platelet aggregation induced by $\mathrm{COL}$, AA and U46619 (9,11-dideoxy-9 $\alpha, 11 \alpha$-methanoepoxyprostaglandin $\mathrm{F}_{2 a}$ ) and ex vivo induced by AA. Taxus baccata presented a significant inhibitory effect on platelet aggregation induced by AA, COL, and platelet activating factor at a concentration of $400 \mu \mathrm{g} / \mathrm{mL}$ (Erdemoglu et al., 2004).

According to Dong et al. (1998), substances with antiaggregant activity are found in plants and the flavonoids are the most important class. Mesa et al. (2002) have demonstrated the capacity of the flavonoids naringin, naringenin, hesperidin e hesperetin from citric plants to inhibit platelet-aggregation stimulated by COL in human PRP. Flavonoids are capable of inhibiting lipid peroxidation and platelet aggregation by acting on enzyme systems such as cyclooxygenases and lipoxygenases and interfering in the production of metabolites of AA (Silva

Table 2 - Continuation.

\begin{tabular}{|c|c|c|c|c|c|}
\hline \multirow[t]{2}{*}{ Species } & \multirow[t]{2}{*}{ Part } & \multirow{2}{*}{$\begin{array}{c}\text { Extraction } \\
\text { Solvent }\end{array}$} & \multicolumn{3}{|c|}{$\begin{array}{c}\text { Platelet Aggregating Agents } \\
\text { (Avg \% inhibition) }\end{array}$} \\
\hline & & & ADP & ADR & COL \\
\hline \multirow{6}{*}{ Elaeoluma nuda } & \multirow{3}{*}{ Leaf } & $\mathrm{CHCl}_{3}$ & 25 & 11 & 10 \\
\hline & & $\mathrm{CH}_{3} \mathrm{OH}$ & 16 & 12 & 11 \\
\hline & & $\mathrm{H}_{2} \mathrm{O}$ & 5 & 4 & 0 \\
\hline & \multirow{3}{*}{ Branch } & $\mathrm{CHCl}_{3}$ & 0 & 2 & 22 \\
\hline & & $\mathrm{CH}_{3} \mathrm{OH}$ & 11 & 38 & 47 \\
\hline & & $\mathrm{H}_{2} \mathrm{O}$ & 19 & 8 & 28 \\
\hline \multirow{6}{*}{ Lacmellea gracilis } & \multirow{3}{*}{ Leaf } & $\mathrm{CHCl}_{3}$ & 14 & 13 & 34 \\
\hline & & $\mathrm{CH}_{3} \mathrm{OH}$ & 15 & 11 & 12 \\
\hline & & $\mathrm{H}_{2} \mathrm{O}$ & nt & $\mathrm{nt}$ & $\mathrm{nt}$ \\
\hline & \multirow{3}{*}{ Branch } & $\mathrm{CHCl}_{3}$ & 6 & 11 & 63 \\
\hline & & $\mathrm{CH}_{3} \mathrm{OH}$ & 0 & 0 & 18 \\
\hline & & $\mathrm{H}_{2} \mathrm{O}$ & 2 & 16 & 16 \\
\hline \multirow{6}{*}{ Moutabea guianensis } & \multirow{3}{*}{ Leaf } & $\mathrm{CHCl}_{3}$ & 48 & 21 & 23 \\
\hline & & $\mathrm{CH}_{3} \mathrm{OH}$ & 3 & 6 & 1 \\
\hline & & $\mathrm{H}_{2} \mathrm{O}$ & 0 & 0 & 1 \\
\hline & \multirow{3}{*}{ Branch } & $\mathrm{CHCl}_{3}$ & 19 & 22 & 33 \\
\hline & & $\mathrm{CH}_{3} \mathrm{OH}$ & 3 & 4 & 0 \\
\hline & & $\mathrm{H}_{2} \mathrm{O}$ & 4 & 0 & 0 \\
\hline \multirow{6}{*}{ Paypayrola grandiflora } & \multirow{3}{*}{ Leaf } & $\mathrm{CHCl}_{3}$ & 72 & 98 & 95 \\
\hline & & $\mathrm{CH}_{3} \mathrm{OH}$ & 30 & 12 & 29 \\
\hline & & $\mathrm{H}_{2} \mathrm{O}$ & 51 & 63 & 57 \\
\hline & \multirow{3}{*}{ Branch } & $\mathrm{CHCl}_{3}$ & 7 & 23 & 18 \\
\hline & & $\mathrm{CH}_{3} \mathrm{OH}$ & 27 & 6 & 3 \\
\hline & & $\mathrm{H}_{2} \mathrm{O}$ & 8 & 2 & 8 \\
\hline
\end{tabular}


Table 2 - Continuation.

\begin{tabular}{|c|c|c|c|c|c|}
\hline \multirow[t]{2}{*}{ Species } & \multirow[t]{2}{*}{ Part } & \multirow{2}{*}{$\begin{array}{c}\text { Extraction } \\
\text { Solvent }\end{array}$} & \multicolumn{3}{|c|}{$\begin{array}{l}\text { Platelet Aggregating Agents } \\
\text { (Avg \% inhibition) }\end{array}$} \\
\hline & & & ADP & ADR & $\mathrm{COL}$ \\
\hline \multirow{6}{*}{$\begin{array}{l}\text { Pleurisanthes } \\
\text { parviflora }\end{array}$} & \multirow{3}{*}{ Leaf } & $\mathrm{CHCl}_{3}$ & 12 & 28 & 10 \\
\hline & & $\mathrm{CH}_{3} \mathrm{OH}$ & 5 & 4 & 98 \\
\hline & & $\mathrm{H}_{2} \mathrm{O}$ & 0 & 2 & 0 \\
\hline & \multirow{3}{*}{ Vine } & $\mathrm{CHCl}_{3}$ & 0 & 7 & 13 \\
\hline & & $\mathrm{CH}_{3} \mathrm{OH}$ & 20 & 0 & 95 \\
\hline & & $\mathrm{H}_{2} \mathrm{O}$ & 0 & 0 & 0 \\
\hline \multirow{6}{*}{ Sarcaulus brasiliensis } & \multirow{3}{*}{ Leaf } & $\mathrm{CHCl}_{3}$ & 7 & 10 & 18 \\
\hline & & $\mathrm{CH}_{3} \mathrm{OH}$ & 55 & 36 & 54 \\
\hline & & $\mathrm{H}_{2} \mathrm{O}$ & 46 & 53 & 44 \\
\hline & \multirow{3}{*}{ Branch } & $\mathrm{CHCl}_{3}$ & 23 & 9 & 13 \\
\hline & & $\mathrm{CH}_{3} \mathrm{OH}$ & 46 & 59 & 50 \\
\hline & & $\mathrm{H}_{2} \mathrm{O}$ & 65 & 2 & 85 \\
\hline \multirow{6}{*}{$\begin{array}{l}\text { Schoenobiblus } \\
\text { daphnoides }\end{array}$} & \multirow{3}{*}{ Leaf } & $\mathrm{CHCl}_{3}$ & 33 & 20 & 25 \\
\hline & & $\mathrm{CH}_{3} \mathrm{OH}$ & 35 & 28 & 23 \\
\hline & & $\mathrm{H}_{2} \mathrm{O}$ & 0 & 1 & 0 \\
\hline & \multirow{3}{*}{ Branch } & $\mathrm{CHCl}_{3}$ & 1 & 22 & 10 \\
\hline & & $\mathrm{CH}_{3} \mathrm{OH}$ & 43 & 69 & 43 \\
\hline & & $\mathrm{H}_{2} \mathrm{O}$ & 4 & 0 & 5 \\
\hline \multirow{6}{*}{$\begin{array}{l}\text { Sterigmapetalum } \\
\text { obovatum }\end{array}$} & \multirow{3}{*}{ Leaf } & $\mathrm{CHCl}_{3}$ & 9 & 6 & 21 \\
\hline & & $\mathrm{CH}_{3} \mathrm{OH}$ & 10 & 2 & 12 \\
\hline & & $\mathrm{H}_{2} \mathrm{O}$ & 2 & 3 & 0 \\
\hline & \multirow{3}{*}{ Branch } & $\mathrm{CHCl}_{3}$ & 5 & 12 & 18 \\
\hline & & $\mathrm{CH}_{3} \mathrm{OH}$ & 12 & 1 & 94 \\
\hline & & $\mathrm{H}_{2} \mathrm{O}$ & 8 & 2 & 8 \\
\hline \multirow{6}{*}{$\begin{array}{l}\text { Thyrsodium } \\
\text { sprucenum }\end{array}$} & \multirow{3}{*}{ Leaf } & $\mathrm{CHCl}_{3}$ & 11 & 12 & 8 \\
\hline & & $\mathrm{CH}_{3} \mathrm{OH}$ & 42 & 32 & 37 \\
\hline & & $\mathrm{H}_{2} \mathrm{O}$ & 2 & 10 & 13 \\
\hline & \multirow{3}{*}{ Branch } & $\mathrm{CHCl}_{3}$ & 8 & 0 & 7 \\
\hline & & $\mathrm{CH}_{3} \mathrm{OH}$ & 15 & 35 & 39 \\
\hline & & $\mathrm{H}_{2} \mathrm{O}$ & 62 & 59 & 39 \\
\hline $\operatorname{AAS}(C+)$ & & & 79 & 98 & 99 \\
\hline DMSO (C -) & & & 0 & 0 & 0 \\
\hline
\end{tabular}

$\mathrm{C}+=$ Positive control $\mathrm{C}-=$ Negative control, $\mathrm{ADP}=$ adenosine diphosphate, $\mathrm{ADR}$ $=$ adrenalin, $\mathrm{COL}=$ collagen, $\mathrm{nt}=$ not tested et al., 2002). Flavonoids quercetin and myricetin strongly inhibit human platelet aggregation induced by AA and ADP (Hommam et al., 2000). According to Landolfi et al. (1984), flavones chrysin and apigenin inhibit platelet aggregation by inhibiting cyclooxygenase which may lead to increased cAMP (cyclic adenosine monophosphate) levels.

Preliminary phytochemical screening revealed that E. nuda leaves and branches contain saponins. These compounds are presumably the source of the hemolytic activity of extracts prepared from this plant. Phenols, flavonoids, and tannins were detected in D. calycina and E. nuda methanol extracts. P. grandiflora was shown to have phenolic compounds, but no tannins or saponins. Plants rich in tannins are employed in traditional medicine as adstringents with internal and external action in the treatment of microbial infections and as hemostatic agents (Longuefosse, 2003, Gurib-Fakim, 2006). The presence of flavonoids, tannins and/or phenolic compounds in D. calycina and P. grandiflora is probably related to the inhibition of platelet aggregation observed for the extracts of these plants.

It is important to correlate inhibition of platelet aggregation with the absence of hemolytic activity which was in general observed for the plant extracts tested. This correlation indicates in general that the antiaggregant extracts identified in this study present no toxicity towards erythrocyte membrane which favors them for further research aimed at establishing their chemical composition, among other properties.

D. calycina (Annonaceae) is a promising antimicrobial plant (Carneiro et al., 2008) which needs further study to reveal the identity of several antimicrobial substances present in its extracts according autobiography performed on thinlayer chromatographic plates.

In short, several plants from the Amazon forest having no known history of medicinal use have been shown to have inhibitory effects on platelet aggregation or hemolytic action. These data serve as a baseline or minimum of antiplatelet and hemolytic activities (and potential usefulness) of non-

Table 3 - Average percentage inhibition and minimum inhibition concentrations (MIC) of platelet aggregation for the most active extracts from the studied Amazonian plants. For each MIC determination, the inhibition is expressed as an average relative to that of the positive control (acetylsalicylic acid) in each agonist system.

\begin{tabular}{lllll}
\hline \multirow{2}{*}{ Species } & \multirow{2}{*}{ Part } & \multirow{2}{*}{ Extract } & & \multicolumn{2}{l}{ Aggregation Agents (Avg \% inhibition/MIC $\mu \mathrm{g} / \mathrm{mL}$ ) } \\
\cline { 5 - 5 } & & & ADR & COL \\
\hline Chaunochiton kappleri & Branch & $\mathrm{CHCl}_{3}$ & $98 / 25 \pm 4$ & $99 / 17 \pm 7$ \\
Diclinanona calycina & Branch & $\mathrm{CH}_{3} \mathrm{OH}$ & nd & $97 / 25 \pm 4$ \\
Paypayrola grandiflora & Leaf & $\mathrm{CHCl}_{3}$ & $98 / 25 \pm 6$ & $\mathrm{nd}$ \\
Pleurisanthes parviflora & Leaf & $\mathrm{CH}_{3} \mathrm{OH}$ & nd & $98 / 17 \pm 7$ \\
\hline
\end{tabular}

$\mathrm{nd}=$ not determined. $\mathrm{ADR}=$ adrenalin, $\mathrm{COL}=$ collagen . 
medicinal plants from the Amazon forest. Additionally, these data may have use for comparison with results of planned studies on these activities in traditionally-used medicinal plants from the Amazon.

These and other plants are being screened by our lab in collaboration with others as a means to evaluate the unknown potential of the flora of the Amazon region. Chemical fractionation of the more active extracts is underway and is expected to reveal the chemical agents responsible for these biological activities.

\section{ACKNOWLEDGEMENTS}

This research was performed under the INPA-UFAM general collaborative agreement. The authors recognize financial support received from PPBio / MCT / INPA, PPG-7 / MCT / CNPq (Proc. No. 557106/2005-2).

\section{LITERATIRE CITED}

Aparicio, R.M.; Garcia-Celma, M.J.; Vinardell, M.P.; Mitjans, M. 2005. In vitro studies of the hemolytic activity of microemulsions in human erythrocytes. Journal of Pharmaceutical and Biomedical Analysis, 39: 1063-1067.

Basila, D.; Yuan, C.-S. 2005. Effects of dietary supplements on coagulation and platelet function. Thrombosis Research, 117: 49-53.

Born, G.V.R. 1962. Aggregation of blood platelets by adenosine diphosphate and its reversal. Nature, 194: 927-29.

Brito, M.A.; Silva, R.F.M.; Brites, D. 2002. Bilirubin induces loss of membrane lipids and exposure of phosphatidylserine in human erythrocytes. Cell Biology and Toxicology, 18: 181-192.

Bukowska, B.; Kowalska, S. 2004. Phenol and catechol induce pre-hemolytic and hemolytic changes in human erythrocytes. Toxicology Letters, 152: 73-84.

Bydlowski, S.P.; Yunker, R.L.; Subbiah, M.T.R. 1988. A novel property of an aqueous guaraná extract (Paullinia cupana): inhibition of platelet aggregation in vitro and in vivo. Brazilian Journal of Medical and Biological Research, 21: 535-8.

Carneiro, A.L.B.; Teixeira, M.F.M.S.; Oliveira, V.M.A.; Cauper, G.S.B.; Pohlit, A.M. 2008. Screening of Amazonian plants from the Adolpho Ducke Forest Reserve, Manaus, state of Amazonas, Brazil, for antimicrobial activity. Memorias do Instituto Oswaldo Cruz, 103: 31-38.

Dong, H.; Chen, S.-X.; Xu, H.-X.; Kadota, S.; Namba, T. 1998. A new antiplatelet diarylheptanoid from Alpinia blepharocalyx. Journal of Natural Products, 61: 142-144.

Ducke Reserve 2004. www.curupira.inpa.gov.br/projetos/ducke/cducke.htm1. Date of access: 11/13/2004.
Erdemoglu, N.; Sener, B.; Teng, C.M. 2004. Pharmacological activity of Taxus baccata. Pharmaceutical Biology, 42: 135-137.

Gandhi, V.M.; Cherian, K.M. 2000. Red cell haemolysis test as an in vitro approach for the assessment of toxicity of karanja oil. Toxicology In Vitro, 14: 513-516.

Gurib-Fakim, G. 2006. Medicinal plants: traditions of yesterday and drugs of tomorrow. Molecular Aspects of Medicine, 27: 1-93.

Hommam, M.M.; Taniguchi, O.; Okak, M.N.; Tsuma, T. 2000. Inhibitory effects of lignans and flavonoids in saibokuto, a herbal medicine for bronchial asthma, on the release of leukotrienes from human polymorphonuclear leukocytes. Planta Medica, 66: 88-91.

Jensen, R.; Gordon, E. 1992. Antiplatelet therapy. Clinical Hemostasis Reviews, 6: 1-4, Denver (U.S.A.).

Kublik, H.; Bock, T.K.; Schreier, H.; Müller, B.W. 1996. Nasal absorption of 17-ß estradiol from different cyclodextrin inclusion formulations in sheep. European Journal of Pharmaceutics and Biopharmaceutics, 42: 320-24.

Landolfi, R.; Mower, R.L.; Steiner, M. 1984. Modification of platelet function and arachidonic acid metabolism by bioflavonoids. Biochemical Pharmacology, 33: 1525-30.

Longuefosse, J.L. 2003. Plantes Médicinales de la Caraïbe. Gondwana Editions. 2v Ilust.

Matos, F.J.A. 1997. Introdução a Fitoquímica Experimental. 2nd ed., Ediçôes UFP, Fortaleza (Brazil).

Mesa, M.G.; Herrera, D.M.A.; Vilas, M.M.; Alfonso, C.C.; Carretero, J.H.; Batista, A.D.; Montequín, J.I.F. 2002. Plantas cítricas no tratamento de enfermidades vasculares. Revista Cubana de Angiologia e Cirugia Vascular, 3: 39-46.

Ribarov, S. R.; Bemov, L.C. 1981. Relationship between the hemolytic action of heavy metals and lipid peroxidation. Biochimica et Biophysica Acta, 640: 721-726.

Sanabria, R.R.; Fournet, A.; Rojas, A.A.; Sanabria, L.M.; Nakayama, H. 1997. Inhibición de la agregación plaquetária por extractos de plantas de uso medicinal en Paraguay. Efacim-Eduna, Asunción (Paraguay).

Saw, J.T.; Bahari, M.B.; Ang, H.H.; Lim, Y.H. 2006. Potential drug-herb interaction with antiplatelet/anticoagulant drugs. Complementary Therapies in Clinical Practice, 12: 236-241.

Silva, R.R.; Oliveira, T.T.; Nagem, T.J.; Leão, M.A. 2002. Efeito de flavonóides no metabolismo do ácido araquidônico. Revista de Medicina-Ribeiráo Preto, 35: 127-133.

Son, D.J.; Cho, M.R.; Jin, Y.R.; Kim, S.Y.; Park, Y.H.; Lee, S.H.; Akiba, S.; Sato, T.; Yun, Y.P. 2004. Antiplatelet effect of green tea catechins: a possible mechanism through arachidonic acid pathway. Prostaglandins, Leukotrienes and Essential Fatty Acids, 71: 25-31.

Undas, A.; Brummel-Ziedins, E.; Mann, K.G. 2007. Antithombotic properties to aspirin: beyond strictly antiplatelet actions. Blood, 109: 2285-2292. 
WHO 1998. Quality control methods for medicinal plant materials. World Health Organization (WHO), Geneva. p. 41-43.

Yamamoto, T.; Tsurumaki, Y.; Takei, M.; Hosaka, M.; Oomori, Y. 2001. In vitro method for prediction of the phototoxic potentials of fluoroquinolones. Toxicology In Vitro, 15: 721-727.

Zucker, M.B. 1989. Platelet aggregation measured by the photometric method. Methods in Enzymology, 169: 117-13.

Recebido em 01/11/2008

Aceito em 14/02/2009 